\title{
Evaluation of reservoir performance by waterflooding: case based on Lanea oilfield, Chad
}

\author{
Mahamat Tahir Abdramane Mahamat Zene ${ }^{1} \cdot$ Nurul Hasan $^{2}$ (i) $\cdot$ Ruizhong Jiang ${ }^{1} \cdot$ Guan Zhenliang ${ }^{3}$. \\ Nurafiqah Abdullah ${ }^{2}$
}

Received: 26 August 2020 / Accepted: 3 February 2021 / Published online: 6 March 2021

(c) The Author(s) 2021

\begin{abstract}
The research of the current study is primarily focused on evaluating the reservoir performance by utilizing waterflood technique, based on a case study at Lanea oil field located in Chad; various mechanisms along with approaches were used in considering the best suitable pattern for waterflooding. All the simulation work was compared against a base case, where there was no involvement of water injection. Moreover, for the base case, a significant amount of oil left behind and cannot be swept, because of lower reservoir pressure at the downhill. The recovery factor obtained was in the range of $14.5-15 \%$ since 2010, and in order to enhance the oil production, an injection well was applied to boost the reservoir pressure; oil recovery is improved. In addition, sensitivity analysis study was performed to reach the optimum production behavior achieved by possible EOR method. Parameters, such as grid test, injection position, proper selection production location, permeability, and voidage substitution, were defined in the simulation study.
\end{abstract}

Keywords Evaluation of reservoir performance $\cdot$ Waterflooding $\cdot$ Primary energy $\cdot$ Lanea oilfield $\cdot$ Fluid flow simulation

Abbreviations
$\begin{array}{ll}\text { FOE } & \text { Field oil efficiency (\%) } \\ \text { WAG } & \text { Water alternative gas }(-) \\ \text { SWAG } & \text { Simultaneous water and gas }(-) \\ \text { EOR } & \begin{array}{l}\text { Enhanced oil recovery }(\% \text { of increased } \\ \text { recovery) }\end{array} \\ \text { GOC } & \text { Gas-oil contact (m reference to surface) } \\ \text { WOC } & \text { Water-oil contact (m reference to surface) } \\ \text { FOPT } & \text { Field oil production total }\left(\mathrm{SM}^{3} / \text { day }\right) \\ \text { FLPR } & \text { Field liquid production rate }\left(\mathrm{SM}^{3} / \text { day) }\right.\end{array}$

Nurul Hasan

nurulhasan@asme.org

Mahamat Tahir Abdramane Mahamat Zene lb1702005@s.upc.edu.cn

Ruizhong Jiang

jrzhong@126.com

Guan Zhenliang

guanzl@cug.edu.cn

1 College of Petroleum Engineering, China University of Petroleum (East China), Qingdao, China

2 PCE, Universiti Teknologi Brunei, Jalan Tungku Link, Gadong BE1410, Brunei Darussalam

3 Faculty of Earth Resources, China University of Geosciences (Wuhan), Wuhan, China

$\begin{array}{ll}\text { BARSA } & \text { Bars absolute }\left(\mathrm{N} / \mathrm{m}^{2}\right) \\ \text { FOPR } & \text { Field oil production rate }\left(\mathrm{SM}^{3} / \text { day }\right) \\ \text { FWCT } & \text { Field water cut/total L }(\%) \\ \text { FVIR } & \text { Field voidage injection rate }\left(\mathrm{SM}^{3} / \text { day }\right) \\ \text { FVPR } & \text { Field voidage production rate }\left(\mathrm{SM}^{3} / \text { day }\right) \\ \text { FPR } & \text { Field production rate }(\mathrm{BARSA}) \\ \text { FGPT } & \text { Field gas production total }\left(\mathrm{SM}^{3}\right)\end{array}$

\section{Introduction}

Enhanced oil recovery (EOR) has received more attention from the leading Research \& Development organizations. High oil price, global demand, and maturation of oilfield worldwide demand a thorough investigation of this issue (Ogiriki et al. 2018). Oil production can be classified into three stages: primary, secondary and tertiary (or enhanced oil recovery). Primary recovery relies on naturally occurring pressure within the oil reservoir to drive oil to the surface (Ishak et al. 2018). Primary recovery from oil reservoir is influenced by reservoir rock properties, fluid properties, and geological heterogeneity. In general, the primary oil recovery ranges from 20 to $40 \%$ (Sandrea and Sandrea 2007), with an average around $34 \%$. The remainder of hydrocarbon is left behind the reservoir. In the secondary oil recovery,

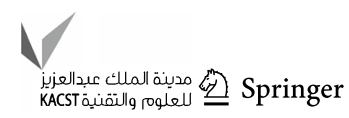


external energy is applied to the oil reservoir when the naturally occurring pressure is no longer sufficient to bring oil to the surface. This is performed by fluid injection (heated or cold), in order to maintain or increase the reservoir pressure (Palsson et al. 2003; Thomas et al. 1987). Generally, secondary recovery comprehends the immiscible process or waterflooding (Abbas et al. 2015) and gas injection or gas-water combination floods, known as water alternative gas (WAG) injection, where slugs of water and gas are injected sequentially. Simultaneous injection of water and gas (SWAG) is practiced because of its availability, low cost, and high specific gravity (Zhou 2015; Morel et al. 2012; Craig et al. 1955)

Crude oil is expected to supply $26 \%$ of the world's energy until 2040 (Kontorovich et al. 2014). Given that the average recovery factor is just about 20-40\% (Allan and Sun 2003) and the majority of the oil reservoir is matured, improving the recovery from the existing field is a priority.

The primary reasons why waterflooding is the most successful and most widely used oil recovery process are that its low cost, ease of injection and high displacement efficiency compared to other methods (Johns et al. 2002).

Luo et al. (2017) and Mohammadi et al. (2009) studied viscous fingering of waterflooding project that has a great impact on all works in the reservoir and concluded that for viscous fingering scenario, water injection is challenging. But heavy oil adds one more complication in terms of EOR (Weijermars and van Harmelen 2017; Brice and Renouf 2008; Alvarado and Manrique 2010; Seright 2010). High movement of water, high water production, viscosity ratio and the water mobility are major issues for heavy oil.

Fractures have a great impact on the prediction performance of the reservoir. Rahman et al. (2017) studied the impact of edge water drive on the reservoir performance and tight zones that are not affected by water which is the lower zone in the field while. The upper zones have high permeability that can be influenced by the support from the aquifer. Khan and Mandal (2019) made a simulation model for the patterns of waterflooding and presented the performance of five-spot waterflooding in an oil reservoir having non-uniform properties in all locations (Saboorian-Jooybari et al. 2016; Brouwer and Jansen 2002; Gharbi et al. 1997).

Hadia et al. (2007) and Asadollahi and Naevdal (2009) showed that the pressure declined very rapidly in the horizontal wells that mean the efficiency of waterflooding is very bad, and therefore, the study proved that the impact of waterflooding is better for the vertical wells than horizontal wells.

Saper et al. (2018) built a simulation model for the effect of the reservoir and fluid parameters on the water coning time for the time of breakthrough and the critical oil rate.

Brice and Renouf (2008) found that the maximum recovery from the reservoir can be achieved by increasing waterflooding rapidly and then decreasing it slowly to get high production of oil and consequently will impact the efficiency of the reservoir. Dai et al. (2016) discovered that recovery increases with production at a high rate until reaching $80 \%$ of total production. The prediction of a simulation study for the waterflooding is not preferable for this case due to that already existing before the application of waterflooding.

Klemm et al. (2018) showed the learning lessons from the application of waterflooding project on the oil reservoir that undergoes for the waterflooding project for 50 years. Sheng et al. (2015) discussed the importance of residual oil saturation on the application of waterflooding project.

Low salinity water is much better than results of waterflooding itself and ensures that on the performance of reservoir the oil recovery can get it from the oil reservoir. Low salinity water is considered a special type of enhanced oil recovery "EOR" such as chemical flooding to get much more oil and better reservoir performance. Yu et al. (2014) applied a waterflooding model for homogeneous properties, but the success of waterflooding relied on the amount of data available for the reservoir and the degree of heterogeneity (AlKandari et al. 2012; Qi and Hesketh 2005) of the reservoir which reflects on the extension of the sand channel in the reservoir.

Turta et al. (2000) proved several factors that will influence on the performance of waterflooding and reservoir such as oil saturation, water saturation, production volume, injected water volume with the sweep efficiency that depend on the shape and heterogeneity of reservoir.

For the secondary production from reservoirs using waterflooding, the reservoir geometry, fluid properties, reservoir depth, lithology and rock properties, fluid saturation, reservoir uniformity, primary reservoir driving mechanisms, mobility ratio and other critical parameters must be thoroughly analyzed. Mobility ratio is defined as the mobility of displacing fluid (gas) divided by the mobility of displaced fluid (crude oil) (Levitt et al. 2013). For the porous (Saeid et al. 2018) medium, the mobility issue must be understood. The API gravity of crude oil in the Lanea oilfield varies from 25 to 34 , theoretically, waterflooding should be effective.

This work has evaluated the reservoir performance on long term (30 years) of waterflooding, fixed on a cumulative goal range of the total field injection. The purpose of this study is planning on evaluating and optimizing waterflood (Ogbeiwi et al. 2018) plan for this study. This study assumed there is no wax or hydrate or sand involved.

The purpose of this research is stated as follows:

- Evaluating the recovery by waterflooding by contrasting recovery efficiency, and deciding on the optimum recovery.

- Investigating the parameters affecting the reservoir performance. 


\section{Methodology}

Schlumberger Eclipse 100 is used to solve mass conservation model for evaluating the reservoir performance of waterflooding based on the Base_Case (Table 3) of Lanea oilfield.

The methodology involves building a geological model, defining model properties, defining physical properties, waterflood performance and finally conducting sensitivity analysis as shown in Fig. 1. Zene et al. (2019b) and Dou et al. (2018) provide more details about the geological modeling of Bongor Basin.

A 3D five-spot pattern ( $\mathrm{Li}$ et al. 2014; Ogbeiwi et al. 2018) reservoir model is built as an initiation for the simulation (Abdullah et al. 2020; Sern et al. 2012) realization. The constructed model is based on a currently producing reservoir (Zene et al. 2019a, b; Ogbeiwi et al. 2018; Xin et al. 2018). The deposits (Bongor Basin) are mainly mudstones and high-potency kerogen shales interspersed with medium-large sandstone (with large granularity) (Mohyaldin et al. 2019). To accurately estimate the efficiency of a waterflooding process, an assessment of the impact of sand discontinuities or connectivity in these reservoirs is required for realistic performance predictions of the schemes and estimation of associated confidence limits. The presence of flow barriers caused by these shales and variations in directional permeability across the reservoir strongly affects the drainage patterns and the sweep efficiency of water injection processes. In Lanea oilfield with the primary recovery less oil is recovered and much left behind; then, introducing a secondary recovery will improve the recovery efficiency. Table 2 shows the base case property and physical properties on which these methods were applied. In the base case test scenarios the permeability replaced by it is average value: $179 \mathrm{mD}$. It could be changed to $179 \mathrm{mD}$.

The economic evaluation highlights the risk analysis which leads to net present value (NPV) of the project. Figures 2 and 3 present further details about the evaluation (Table 1).

Table 2 shows an approximate calculation of internal rate of return. As this is not the main core objective, the details will not be explained here.

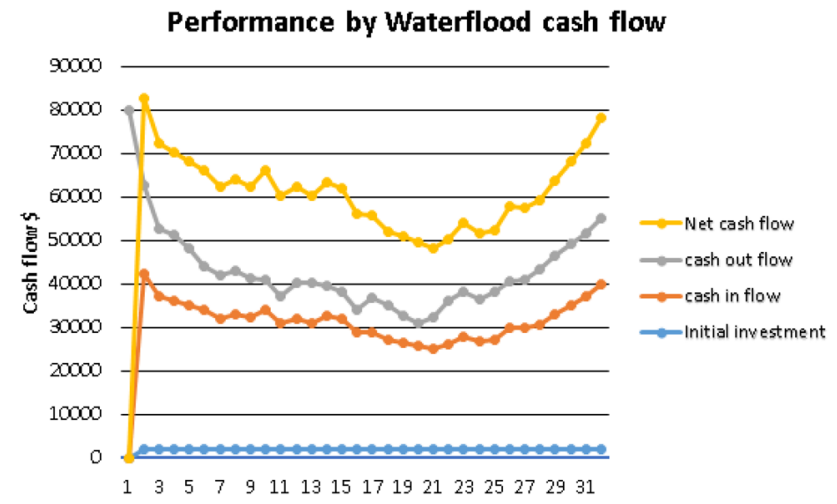

Fig. 2 The comparison of calculated NPV based on the initial investment (based on years), cash inflow, cash outflow, and net cash flow
Fig. 1 Workflow and methodology of the usage of the data

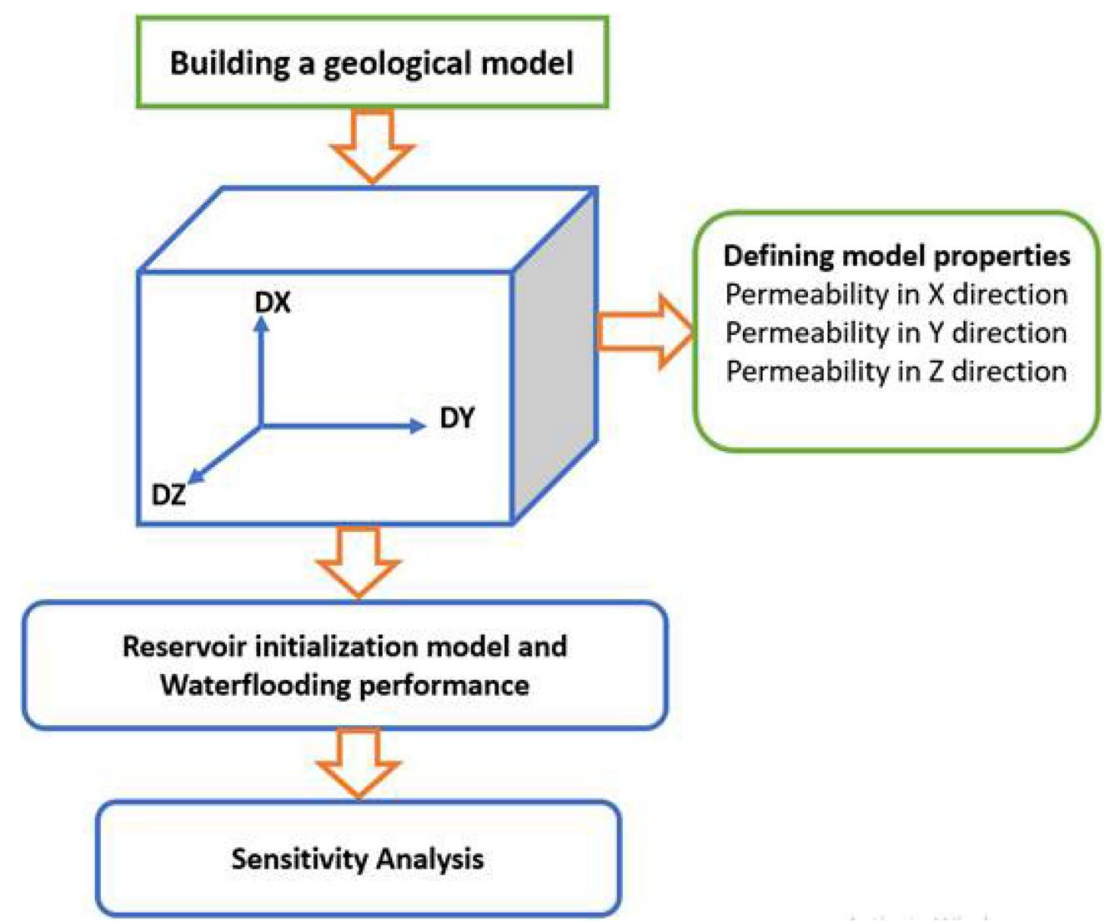




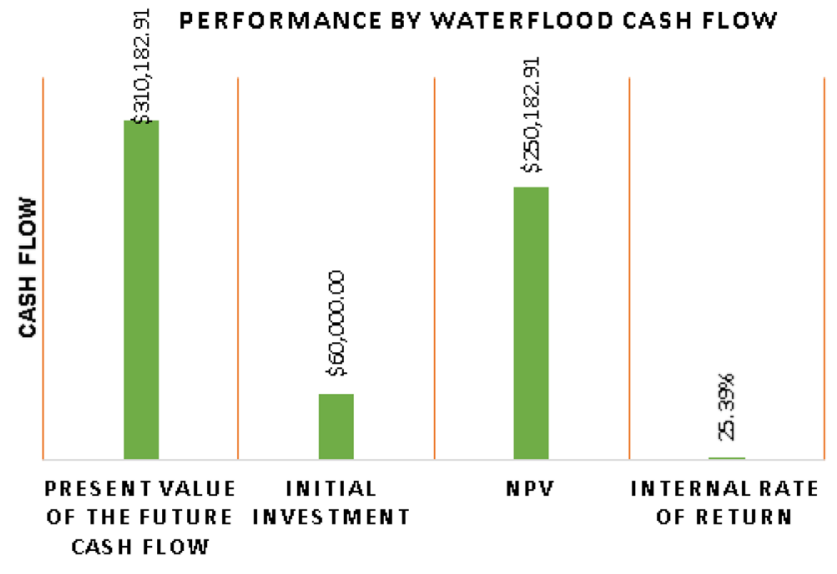

Fig. 3 Comparison based on the present value of the future cash flow, initial investment, NPV and the internal rate return

Table 1 Rate of return calculation

Present value of the future cash flow

$\$ 303,379.76$

Initial investment

$\$ 60,000.00$

NPV

$\$ 243,379.76$

Internal rate of return

$25.43 \%$

A bar chart (Fig. 3) shows a clear indication of value of rate of return.

\section{List of test cases and justification}

The following test cases (Table 3) are simulated and analyzed: effect of grid layer (Case1), the effect of the location of production well (Case2), effect of permeability (Case3) and effect of voidage substitution (Case4). In Case0, the injection takes place on the same Base_Case (no injection). Injected rate, number of the producer wells as well the injector wells, design condition, volume of injection and production duration have to be understood.

Lanea blocks are of medium porosity and high permeability, with a porosity of $13.2-24.3 \%$ (22.0\% on average) and a permeability of 179 .

Figure 4 shows the initial 3D model before waterflooding (Base_Case of Table 2). Reservoir initial pressure is 9572.49 psi (Table 2), while the depth of the top faces is $4000 \mathrm{ft}$. All total 13 wells (Lanea 1, Lanea 2, Lanea 3, Lanea 4, Lanea 5, Lanea 6, Lanea 7, Lanea 8, Lanea 9, Lanea 10, Lanea 11, Lanea 12, and Lanea 13) considered in this model are production well for the base model (Base_Case of Table 2) (Fig. 5).

During the implementation of the waterflooding performance evaluation the well of Lanea 13 converted to water injection well (INJ). The base model (Base_Case and Case0) built by cells of grid blocks in total 8000 is active. X and Y dimensions of grids blocks size are $40 \mathrm{ft}$. It is separated into five layers from top to bottom. That means the average thickness of a 1 layer is $5 \mathrm{ft}$. Water-oil contact (WOC) is $4100 \mathrm{~m}$, and the gas-oil contact (GOC) is $3900 \mathrm{~m}$.

\section{Results and discussion}

Figure 6 (top left) shows different field result graphs for Case0, FOPT versus time, the starting field oil production total of $5995 \mathrm{SM}^{3}$ in day 1 continuously increasing till on it is highest to $7 \times 10^{6} \mathrm{SM}^{3}$ in 11175 days.

Figure 6 (top right) states the different field result graphs of Case0 whic is FPR versus time, FPR versus time, with a rate of 661 bar in day 1 decreased to 81.59 BARSA in 6937
Table 2 Details of the Base Case of the test scenarios

Cell in X direction (DX)
Cell in Y direction (DY)
Cell in Z direction (DZ)
Total cell number
Porosity
Permeability in X direction
Permeability in Y direction
Permeability in Z direction
Gas density
Oil density
Water density
Reference pressure
Water formation volume factor at prefer-
ence
Water compressibility

$\mathrm{X}$ grid block sizes, $\mathrm{ft}$.

Y grid block sizes, $\mathrm{ft}$.

$\mathrm{Z}$ grid block sizes, $\mathrm{ft}$.

Total cell of the block, $\mathrm{ft}$.

Grid block porosity values, $\%$

Permeability in $\mathrm{X}$ direction, $\mathrm{mD}$

Permeability in $\mathrm{Y}$ direction, $\mathrm{mD}$

Permeability in $\mathrm{Z}$ direction, $\mathrm{mD}$

Gas density, $\mathrm{lb}_{m} / \mathrm{ft}^{3}$

Oil density, $\mathrm{lb}_{m} / \mathrm{ft}^{3}$

Water density, $\mathrm{lb}_{m} / \mathrm{ft}^{3}$

Reference pressure, Psia

Water FVF at pref

Water compressibility, Psia
40

40

5

8000

0.22

1500

1500

100

0.062428

53.0638

62.428

9572.49

1

0.000725189 
Table 3 List of test cases and justification for the proposed study

\begin{tabular}{|c|c|c|c|}
\hline Case no. & Special feature & $\begin{array}{l}\text { Perme- } \\
\text { ability } \\
(\mathrm{mD})\end{array}$ & Comments \\
\hline Base_Case & $40 * 40 * 5$ Mesh size & 100 & Starting base case \\
\hline Case0 & $40 * 40 * 5$ Mesh size & 100 & Injection \\
\hline Case1 & $45 * 45 * 5$ Mesh size & 100 & $\begin{array}{l}\text { Testing the effect of } \\
\text { grid }\end{array}$ \\
\hline Case2 & $45 * 45 * 5$ Mesh size & 100 & $\begin{array}{l}\text { Relocated production } \\
\text { well }\end{array}$ \\
\hline Case3 & $45 * 45 * 5$ Mesh size & 500 & Effect of permeability \\
\hline Case4 & $45 * 45 * 5$ Mesh size & 500 & $\begin{array}{l}\text { Effect of voidage } \\
\text { substitution }\end{array}$ \\
\hline
\end{tabular}

days on it is the lowest then increased to it is highest 2502.43 BARSA in 11175 days.

Figure 6 (bottom left): Different field result graphs of Base_Case, FWCT versus time, FWCT versus time case from the day 1 , the injection rate increasing but on 1800 days it has experienced a slight decrease, again started increasing, with a high water cut of $97 \%$ for the period of 7965 days, from that day on it has decreased significantly to 0 .

Figure 6 (bottom right): Different data taken from the Base_Case field, the FOE started increasing from day 1 to 11175 days reached $68 \%$ on it is highest.

Figure 7 shows the FGPT (top left) versus time, FLPT (bottom left) versus time, FLPR (top right) versus time, FOPR (bottom right) versus time for the Case0. FGPT gradually increases and stays constant after 8000 days $\left(7 \times 10^{7}\right)$; FLPR increases linearly till $\sim 8000$ days and then stays constant at $4.6 \times 10^{7}$. Figure 7 (top left) shows field gas production total (FGPT) versus time start from day 0 it (meaning starting from the beginning) has sharply increased till it has reached to $7 \times 10^{7} \mathrm{SM}^{3}$ the curve projection is stable for 1175 days and producing with the same production rate of $7 \times 10^{7} \mathrm{SM}^{3}$. Figure 7 (top right) shows the different field result graphs of Case0, FLPR versus time with a starting rate of $6000 \mathrm{SM}^{3} /$ day increased in 686 days to the highest rate of $11164 \mathrm{SM}^{3} /$ day then in 798 days the rate decreased to $5689 \mathrm{SM}^{3} /$ day, finally reached 1224 days increased to $8869 \mathrm{SM}^{3} /$ day. The field liquid
Fig. 4 Base_Case: reservoir initialization 3D model before Case0

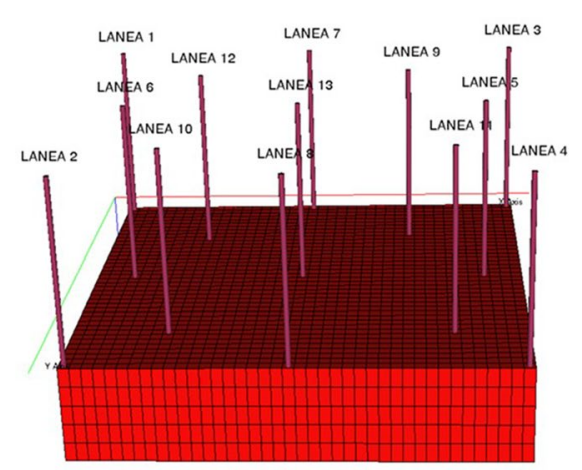

arsen
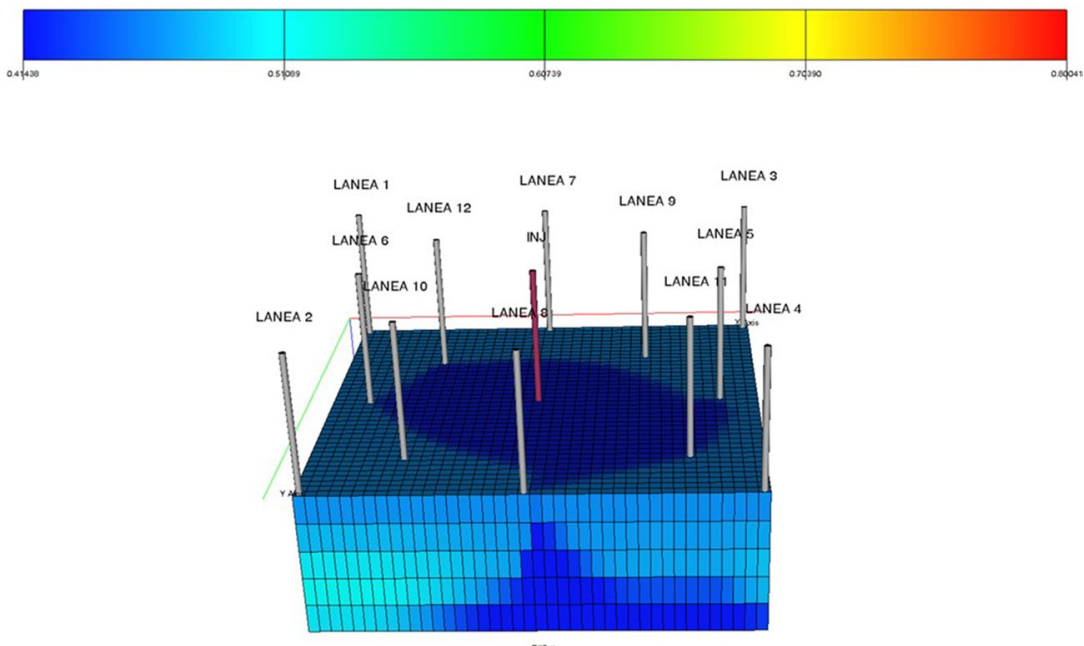

aisest

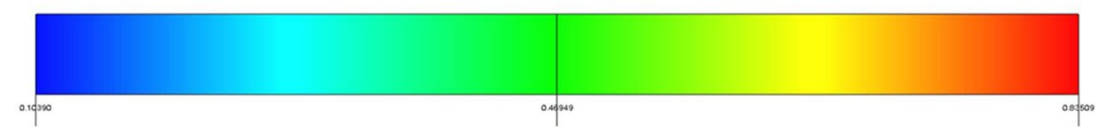



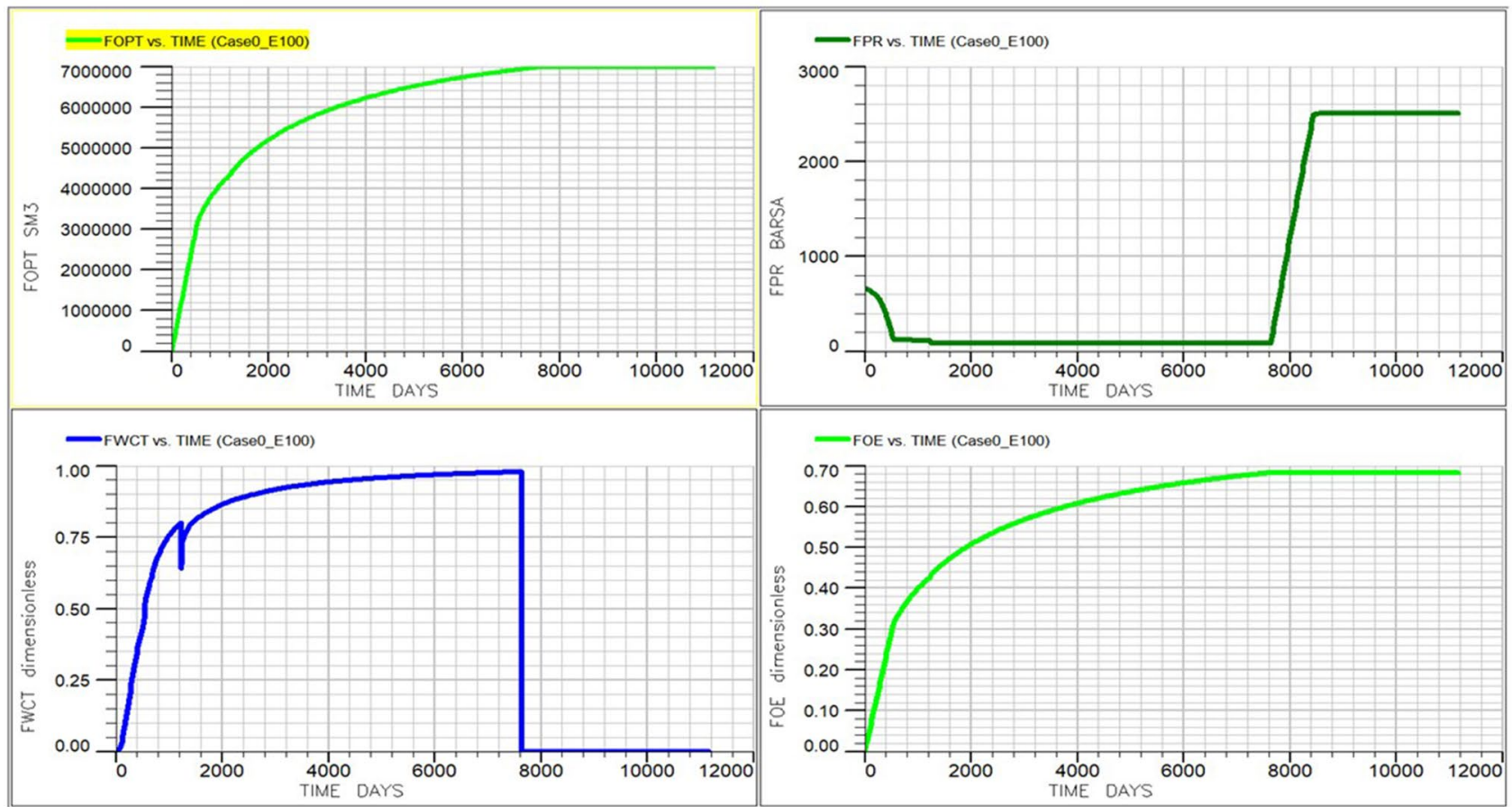

Fig. 6 Case0 waterflood injection case (this case is before the sensitivity analysis cases, Case1) [FOPT, FPR, FWCT and FOE are top left, top right, bottom left, bottom right, respectively]
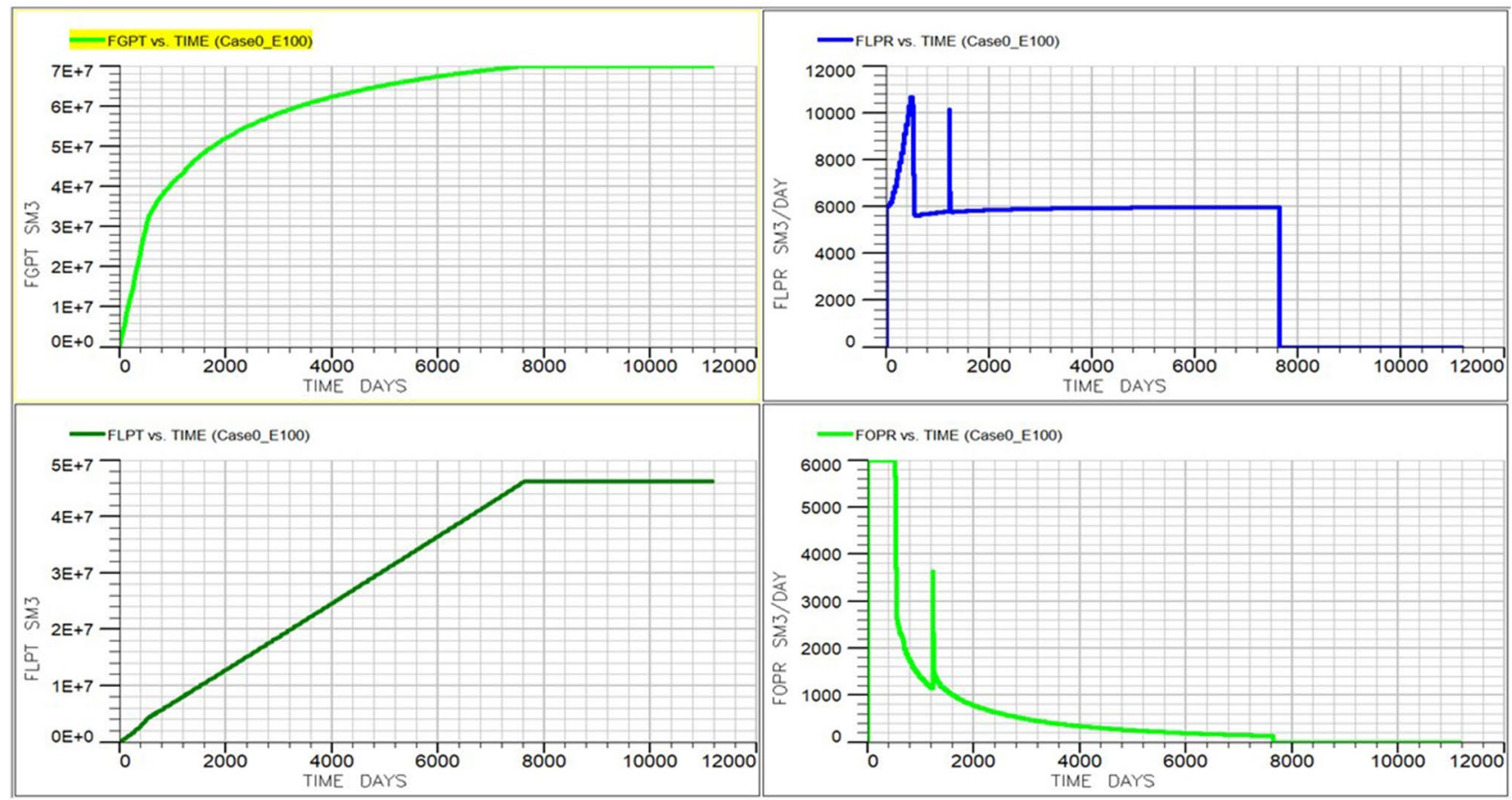

Fig. 7 Case0 injection or waterflood case (this case is before the sensitivity analysis cases) [FGPT (top left) vs time, FLPT (bottom left) vs time, FLPR (top right) vs time, FOPR (bottom right) vs time] 
production rate from 1301 days is $5799.61 \mathrm{SM}^{3} /$ day to $5939.45 \mathrm{SM}^{3} /$ day in 7641 days then the rate has decreased to $0 \mathrm{SM}^{3} /$ day till 11175 days.

Figure 7 (bottom left) states the different field result graphs of waterflood model, FLPT versus time the liquid production total with a starting day $6000.79 \mathrm{SM}^{3}$ has increased significantly to $46761380 \mathrm{SM}^{3}$ in 7641 days. This rate of $46761380 \mathrm{SM}^{3}$ is stable for 11175 days.

Figure 7 (bottom right) Different field result graphs of Waterflood model case, FOPR versus time with a production rate of $5995 \mathrm{SM}^{3} /$ day showing stable for 741 days then immediately decreased to $1872.905 \mathrm{M}^{3} /$ day in 1177 days. The production rate increased for a short period to $1796.51 \mathrm{SM}^{3} /$ day in 1224 days, the production started decreasing in it is lowest to $0 \mathrm{SM}^{3}$ /day in 11175 days.

Figure 8 shows the FVIR (field voidage injection rate) and FVPR (field voidage production rate) for the Case 0 . At the initial stage of injection, there are 2 sudden increase in FVPR, nearly double the FVIR at around 400 and 1200 days in injection. From 1200 days to 7600 days the FVIR and FVPR are at same (6000 $\mathrm{RM}^{3} /$ day), injection needed to stop $\sim 8400$ days as the FVPR drops to zero.

\section{Effect of mesh size}

Oil recovered in the Case 0 model $(40 * 40 * 5)$ is higher than the increased model size Case $1\left(45^{*} 45^{*} 5\right)$ as shown in Fig. 9.

Figure 9 shows an increased model mesh (Zhalehrajabi et al. 2014); after Case 0 , the quantity of non-recoverable oil has increased compared to non-increased model layers (Case1 and Base_Case of Table 3). It can clearly be seen the location of well in Fig. 9.

Figure 10 (left) states the field oil production total, FOPT versus time (Case1 of Table 3 ) starting with a production total of $700 \mathrm{SM}^{3}$ in day 1 continuously increasing without decrease till the curve reached $10 \times 10^{6} \mathrm{SM}^{3}$. Comparing to the Base_Case $\left(7 \times 106 \mathrm{SM}^{3}\right)$ the field oil production total has increased more for the increased model (Case 1 of Table 3). Based on the model layers, more oil is recovered in Lanea 8 from layer 1 to 5 then followed Lanea 2 layer 1, 2 but less in 3 to layer 5, while in Lanea 4, Lanea 1, Lanea 5, Lanea 9 and Lanea 3 is far less.

Figure 10 (right) shows a field liquid production rate, FLPR versus time (right), starting from 6000 FLPT to reach 1100 in 800 days, drops again to 5600 immediately goes up to 8400 at 1200 days and drop back to 5600 and continues to $\sim$ maintain 6000 till 7600 days and drop to zero.

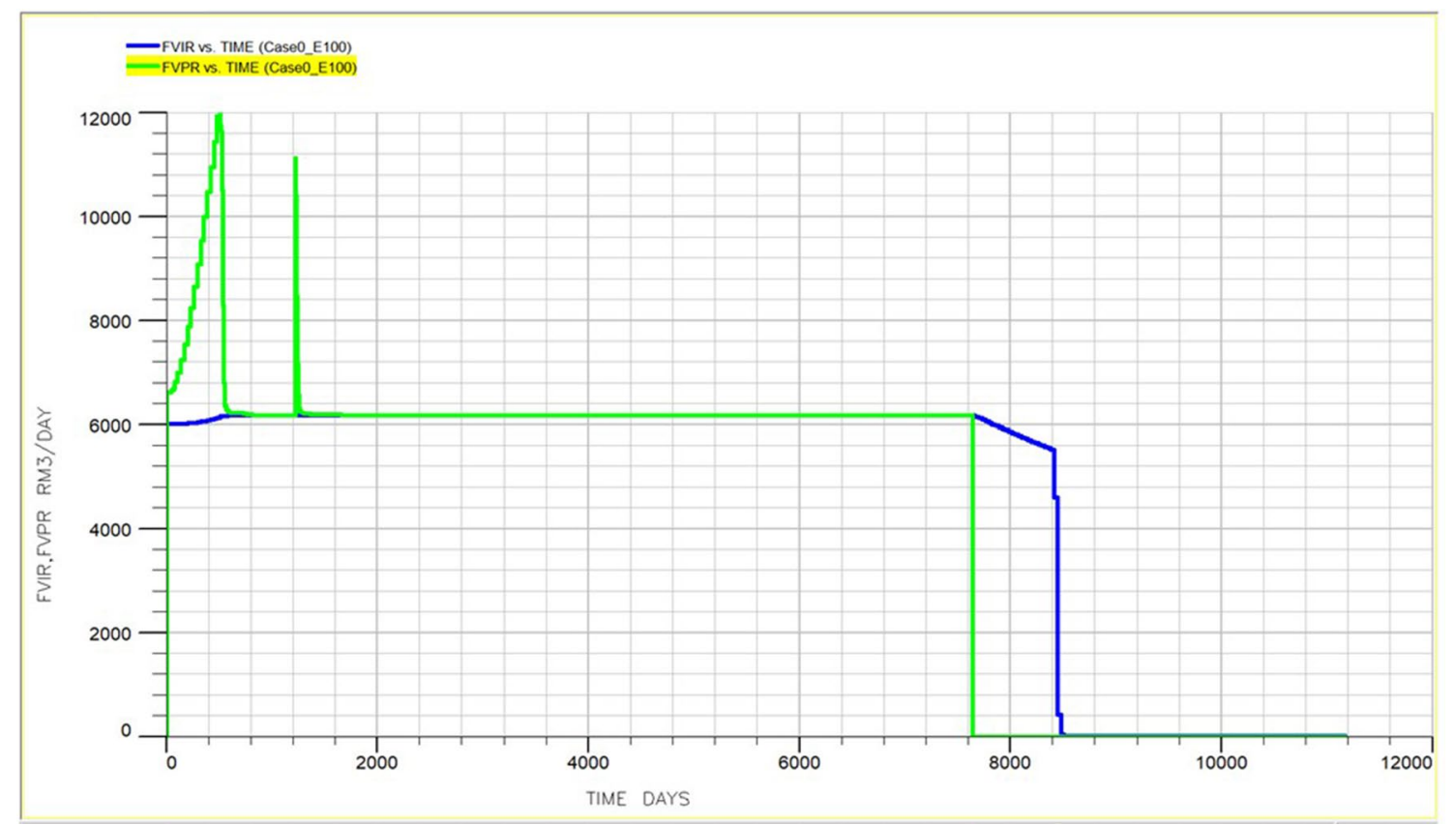

Fig. 8 Case0 waterflood or injection case (FVPR and FVIR) 
Fig. 9 Increased model size after waterflooding (Case1 of Table 3)
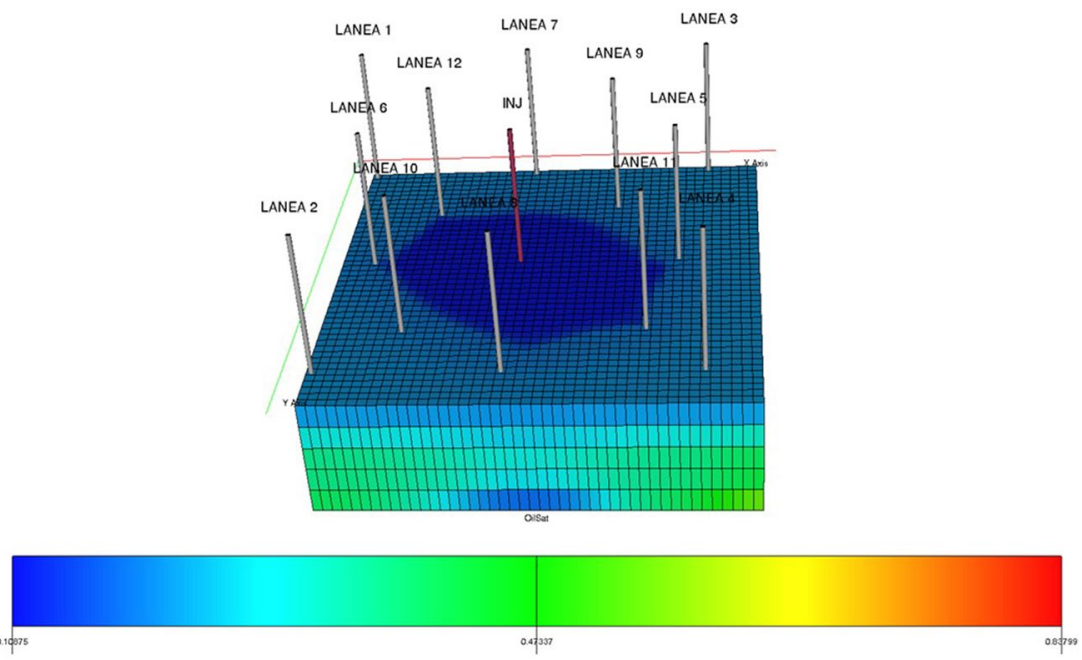

Figure 11 (left) shows the FGPT at day 1 is $5990 \mathrm{SM}^{3}$ on the first day, till has reached on it is highest $10 \times 10^{8} \mathrm{SM}^{3}$ in 8000 days.

Figure 11 (right) gives from the first day with a rate of $6000 \mathrm{SM}^{3}$ on the first day till it has reached on it is highest in 7600 days to $4.67 \times 10^{7} \mathrm{SM}^{3}$.

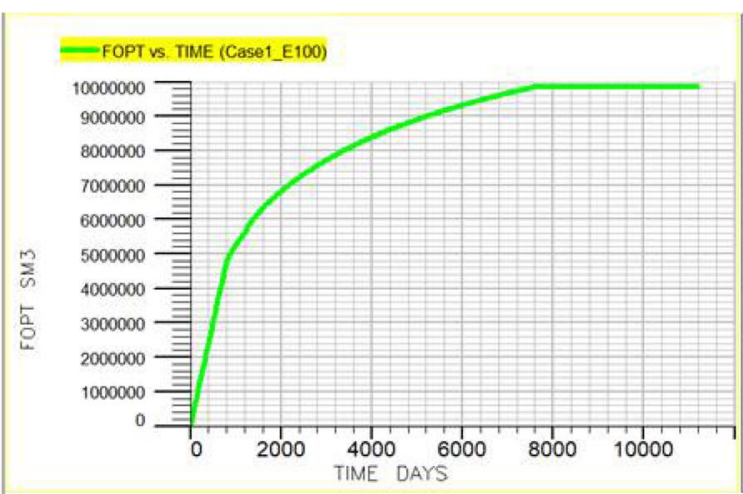

Figure 12 (left) shows field production rate versus time, the production rate is same as the Base_Case did not change, 661 BARSA in day 1 decreased to 81.59 BARSA in 6937 days on it is the lowest then increased to it is highest 2502.43 BARSA in 1175 days.

Fig. 10 Left: field oil production total, right: field liquid production rate (Case1 of Table 3)
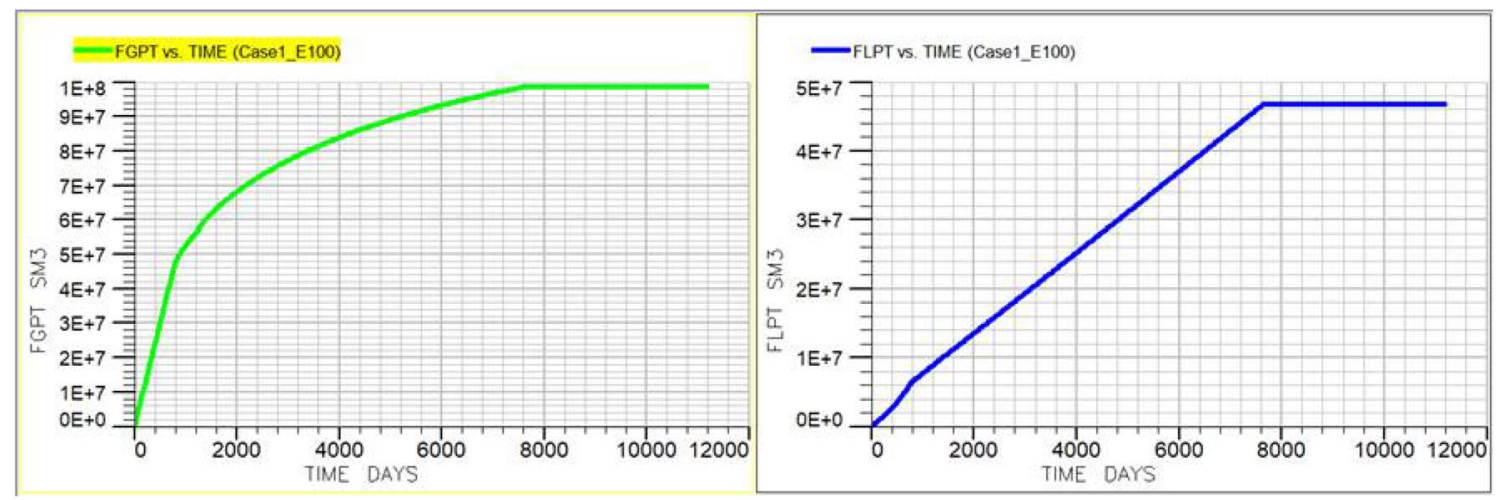

Fig. 11 Left: field gas production total, right: field liquid production total (Case1 of Table 3) 


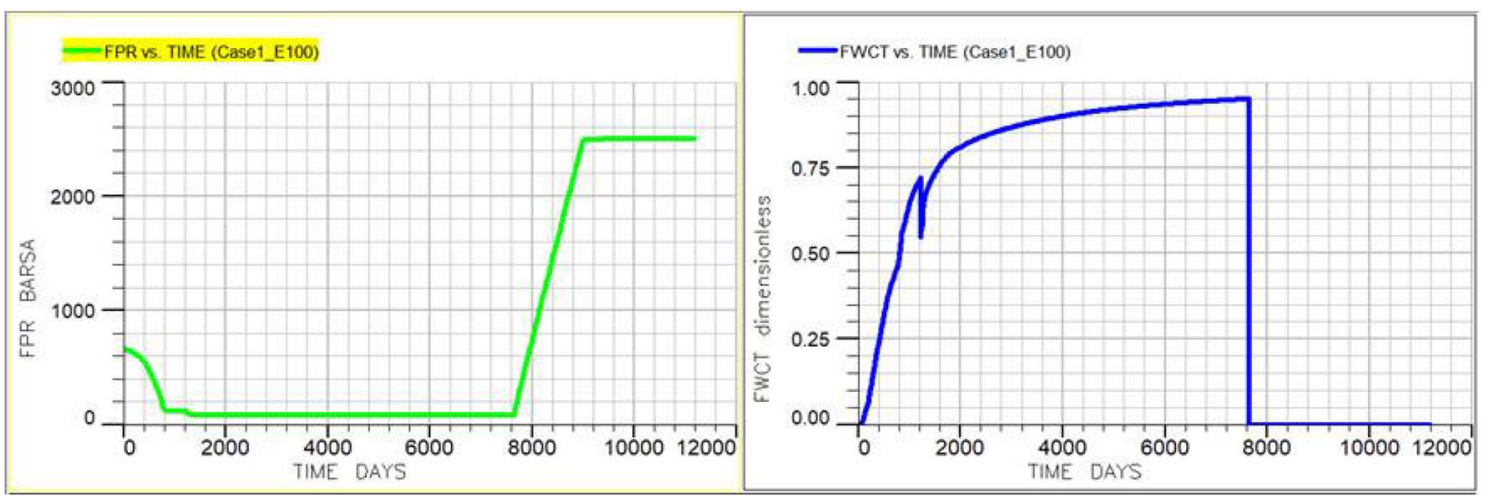

Fig. 12 Case1: left: field production rate, right: field water cut

Fig. 13 Field oil efficiency graph (Case1 of Table 3)

Fig. 14 Oil saturation after waterflood case (Case 2 of Table 3)
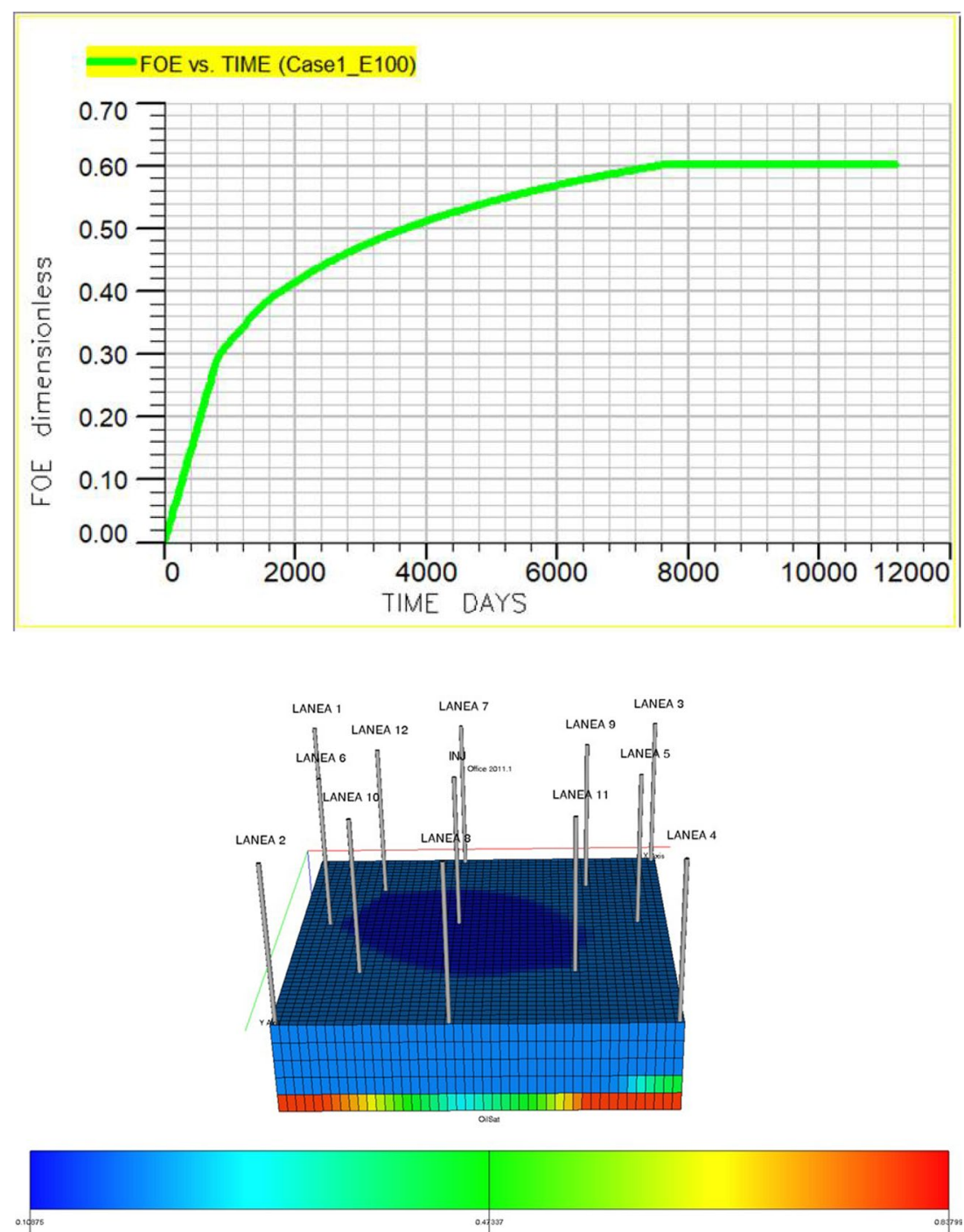

Figure 12 (right): Field water cut, FWCT versus time has increased from zero to $0.95 \%$ in 7596 days then dropped to $0 \%$. There was a sudden spike drop around 1200 days.
With the increase model of $\left(45^{*} 45^{*} 5\right)$ the field oil efficiency (FOE) has decreased to $60.1 \%$ (Fig. 13) compared to the non-decreased model (40*40) FOE which is $68.2 \%$ (bottom right of Fig. 6). 
Fig. 15 Case2: left: field oil efficiency right: field water cut

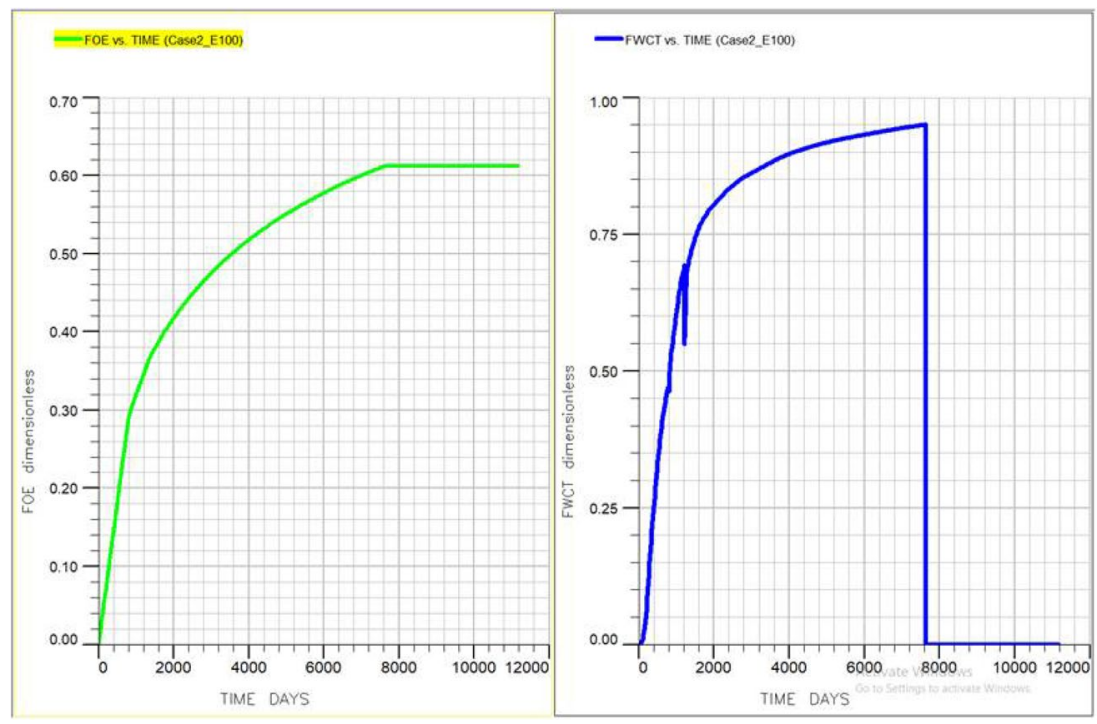

\section{Effect of production location}

Case2 (Table 3) is presented here showing the effect if choosing the right injection at the right place. The biggest question is where to drill and locate the injector well to boost the production. The case is referred as Case 2 in Table 3 where a producer well is converted into injector for the improvement of oil recovery in the same year, the middle well of (LANEA 13) of Base_Case of Table 3. Figure 14 shows the oil saturation for Case2 (Table 3) and clearly shows that most of the oil has already been swept out, but there is more than $20 \%$ of non-recoverable in the reservoir mostly from first layer to the fourth layer.

Most of the oil is recovered in the rest of the layers near the location of Lanea 8; just only $23 \%$ is non-recovered oil in the first layer (Fig. 14). The sequence is Lanea 4, followed by Lanea 11, Lanea 5, Lanea 2, Lanea 4 and Lanea 3 (27\%).
Figure 15 shows the FOE (left) and FWCT, on the right. The maximum value of FOE is 0.62 and FWCT is 0.95 . From 8000 days, the FOE is nearly constant and FWCT drops to zero, same as for the rest of the case studies.

\section{Effect of permeability}

This section presents the effect of permeability (Case 3 of Table 3). The PermZ is $500 \mathrm{mD}$ (Table 3), and mesh is same as Case1 or Case2. Figure 16 (left): Field oil efficiency graph, with the production well relocation the FOE has increased $62.1 \%$ higher than the FOE of Case 1 (Table 3 and Fig. 13) which is $60 \%$.

Figure 16 (right) shows the field water cut (FWCT) graph with time, and if compared with the production well relocation field water cut rate (right of Fig. 15), it remains nearly the same as 0.955 or Case 1 (right of Fig. 12, 0.95).
Fig. 16 Case 3: left: water cut graph, right: fig field oil efficiency

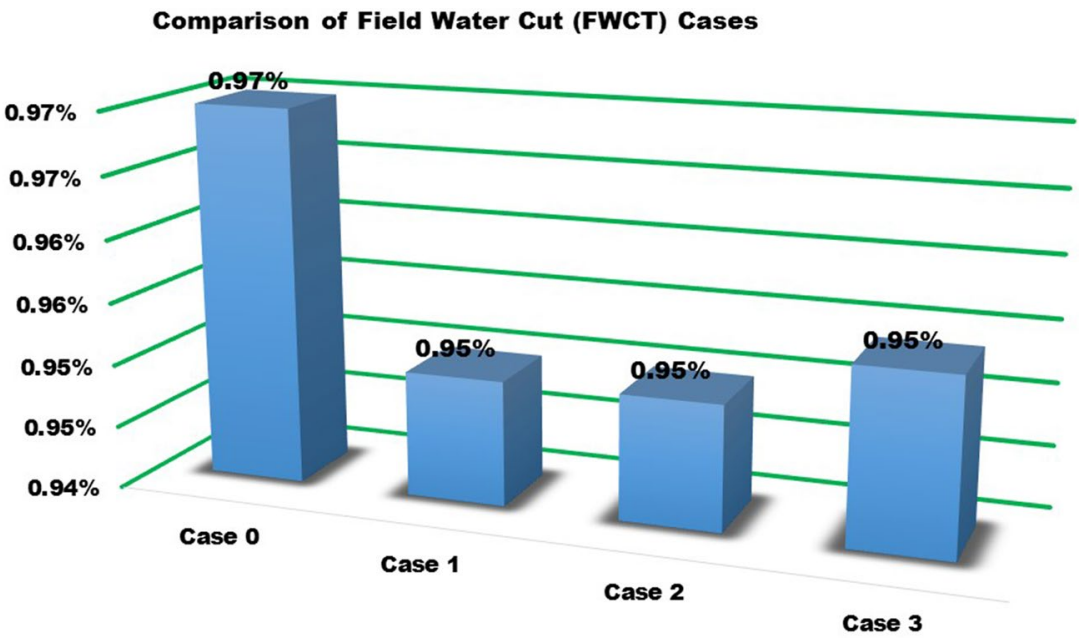


After changing the PermZ to $500 \mathrm{mD}$ from the Case2 (with the production well relocation field water cut rate (right of Fig. 15) it is found from the left of Fig. 16, FOE is decreased to 0.60 compared to 0.612 . As shown in Case_Base (Table 2) with a PermZ $(100 \mathrm{mD})$, FOE (0.6224) and FWCT (0.952\%) are changed. And Fig. 16 (right): Field water cut (FWCT) graph (0.94\%).

\section{Effect of voidage substitution}

This section presents the Case 3 of Table 3, and this is a variation between FVIR and FVPR Case4 (Table 3). It can be observed from the graph that with the increase in model size the Field Voidage Injection Rate (FVIR) from 7628 to 9037 days it has increased to 565 more days compare to Base_Case $(40 * 40 * 5) 7628$ to 8472 days. FVIR means field voidage injection rate, and FVPR means field voidage production rate.

The only control of going through is an ultimate production rate with a rate of $12,377 \mathrm{SM}^{3} /$ Day. Based on our observation, when the production rate increases, the voidage substitution increases. This indicates that the pore spaces are strongly occupied as $90 \%$ or above could explain that there is a possibly that extra oil might be recuperated from this oilfield (Fig. 17).

\section{Conclusion}

Globally, large amounts of hydrocarbon volumes are found in reservoir systems associated with high shale volumes. These shales create discontinuities within the reservoir units.

Figure 18 shows a comparing among different case studies (Case0, Case1, Case3 and Case 2). FWCT versus time
Fig. 17 Variation between FVIR and FVPR (permeability $500 \mathrm{mD}$ )

Fig. 18 Field water cut graph with time for Case0, Case1, Case 2 and Case 3
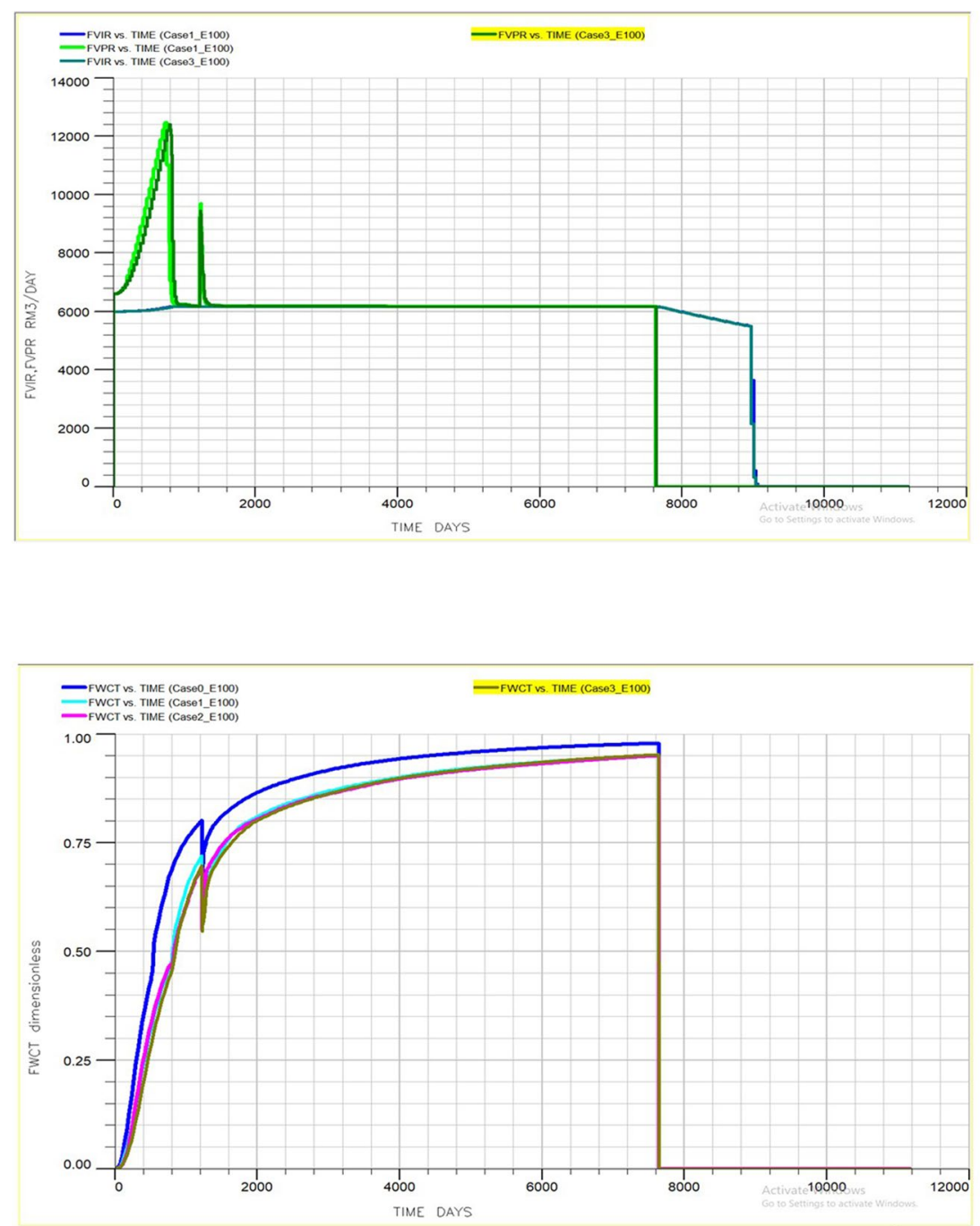


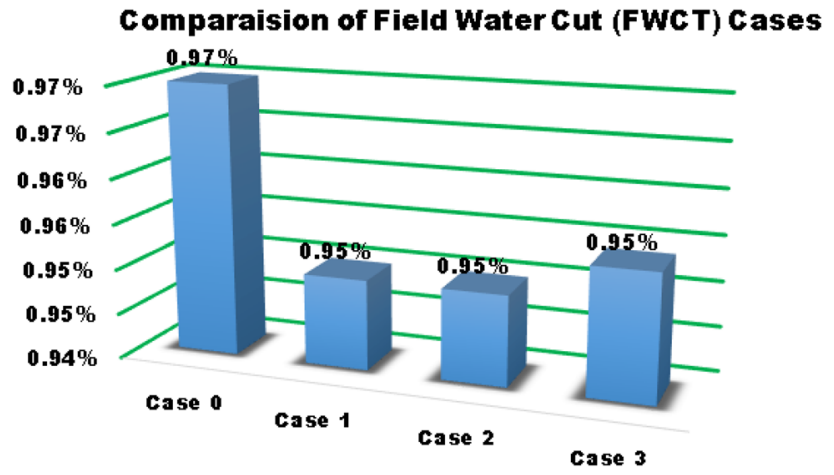

Fig. 19 Maximum field water cut graph for Case0, Case1, Case2 and Case 3

from the day 1 of the injection rate increasing but on around $\sim 1200$ days all have experienced a sudden drop of FWCT for all cases, again started increasing, with the highest water cut for the period of 7965 days, from that day on it has decreased significantly to 0 for all the cases studies here. The water cut for Case 1 of Table 3 has the highest among all the four cases, stating the fact that the outcome depends on the mesh quality. The maximum FWCT is 0.97 for Case 0 and $\sim 0.95$ for Case1, Case2, Case3. More precise numbers are presented next.

From Fig. 18 for all along the injection, FWCT is higher for Case 0 . Around $\sim 800$ days, all cases experience a slight drop of FWCT (Case0 at around 660 days). Case1, Case2, and Case 3 show almost same FWCT till the injection time. It is noteworthy that all cases have dropped the FWCT to same 0.55 and then recover to the increasing trend.

Figure 19 shows the water cut for three cases of Table 3, showing the effect of grid numbers, selection of injection well, and sensitivity of the permeability. Water cut is defined as ratio of the water production to total liquid production. FWCT is same for Case1 and Case2 (0.95). For Case0 (0.97), the water cut is highest. For the Case3, the water cut is 0.955 .

Figure 20 shows the FOE for the Case1, Case 2 and Case 3 over the time period of 11175 days ( $~ 30$ years). The FOE has a range of 0 to 1 as per the definition. Case 0 offers higher FOE compared to Case1, Case 2 and Case 3 , so the quality of mesh is important as can be evidenced. The next in line of FOE is Case3, Case2 and Case1, so the choice of injection and production location is important. Until $\sim 800$ days, the slope of Case1, Case 2 and Case 3 is same (corresponding FOE is 0.29) and slope of Case 0 is always higher from the start. Beyond 800 days, Case 3 is slightly higher than Case 1 and Case2, and after 5000 days, all the FOE are flat to the horizontal axis $(\mathrm{Case} 0=68.2 \%$, Case $1=61.1 \%$, Case $2=$ $62 \%$ Case $3=62.1 \%$ ) and do not change any further. So after near 21 years, the injection does not offer anything more of FOE. So in this case the permeability has less effect on the

\section{Comparaison of FOE}

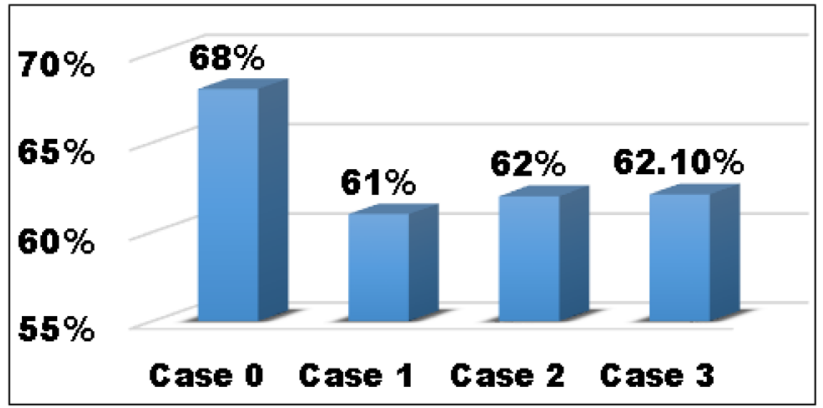

Fig. 21 Comparison of FOE among Case1, Case2 and Case3. Please refer to Table 3
Fig. 20 Field oil efficiency graph with time for Case0, Case1, Case 2 and Case3. Please refer to Table 3

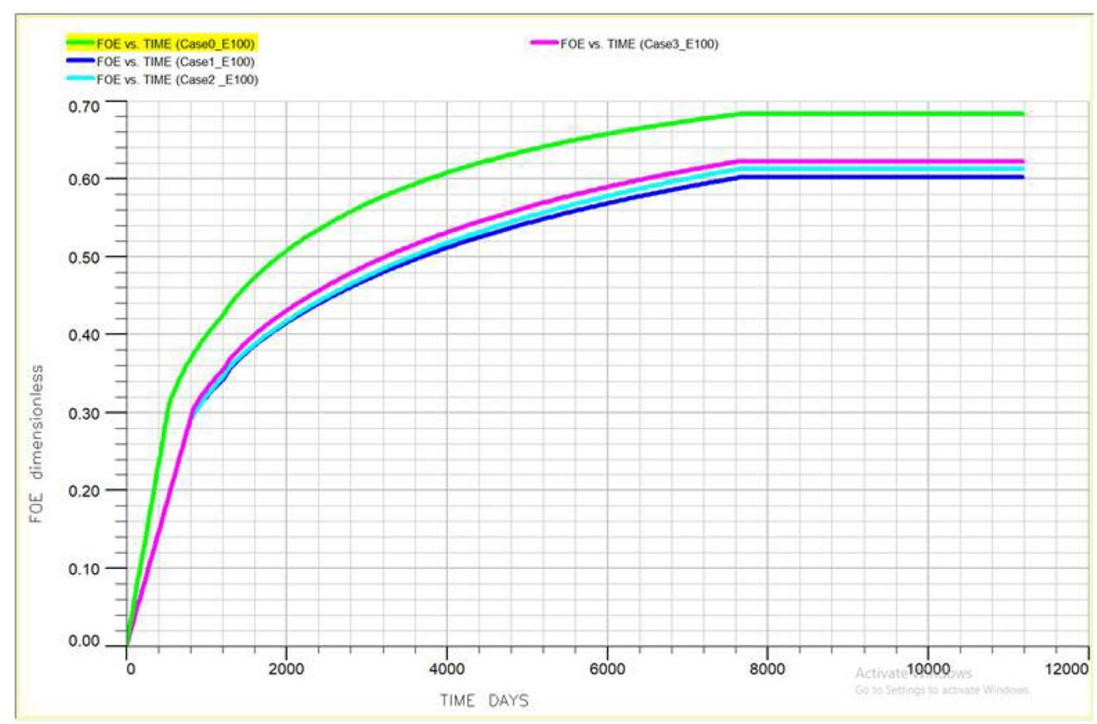


FOE (only $1 \%$ increase in FOE even though the $\mathrm{K}$ has been multiplied by 5 ).

Figure 21 shows a comparison of the highest FOE among the Case0, Case1, Case2 and Case3 (Table 3) after 21 years of injection of water. The highest field of efficiency with the best oil recovery scenario is Case 0 , followed by Case 3 (0.621), Case 2 (0.62) and finally Case1 (0.611). These are significant FOEs by themselves, and this achievement can further be enhanced by choosing the right selection of the production and injection well (Case2). Comparing between Case 1 and Case2, it can be concluded that the FOE is not permeability controlled for this study.

\section{Conclusions}

This work has offered a demonstration of case study which has been approached by the waterflood plan mechanism on Lanea oilfield, Chad. A computational model is studied as the following: building a geological model, defining model properties, defining physical properties, and evaluating the oil recovery. Before preparing for a boosting waterflood performance plan, few sensitivity analysis (grid test, injection or production location selection, permeability, voidage substitution) was performed for the best possible EOR.

For the Case1 (grid test), the EOR is $61.1 \%$, for the Case2 (injection/ production location selection test), the EOR can be as high as $62.0 \%$ and for the Case 3 (permeability test), the EOR is $62.1 \%$. On the other hand, the water cut is 0.95 , 0.95 and 0.954 , respectively. For Case 0 , these numbers are $68.2 \%$ and 0.97 , respectively.

The present research indicates in Figs. 4 and 5 that a model has already been built and then different cases have been tested by comparing each other that could be observed in Table 2.

Funding This is certify that the journal article is prepared without any formal funding. However, Schlumberger donated software to perform research.

Open Access This article is licensed under a Creative Commons Attribution 4.0 International License, which permits use, sharing, adaptation, distribution and reproduction in any medium or format, as long as you give appropriate credit to the original author(s) and the source, provide a link to the Creative Commons licence, and indicate if changes were made. The images or other third party material in this article are included in the article's Creative Commons licence, unless indicated otherwise in a credit line to the material. If material is not included in the article's Creative Commons licence and your intended use is not permitted by statutory regulation or exceeds the permitted use, you will need to obtain permission directly from the copyright holder. To view a copy of this licence, visit http://creativecommons.org/licenses/by/4.0/.

\section{References}

Abbas AGA, Mohammed AAE, Awad LAH, Ibraheem MAM (2015) Feasibility study of improved oil recovery through waterflooding in Sudanese oil field (case study)

Abdullah N, Hasan N, Saeid N, Mohyaldinn ME, Zahran ESMM (2020) The study of the effect of fault transmissibility on the reservoir production using reservoir simulation-Cornea Field, Western Australia. J Pet Explor Prod Technol 20:739-753

Al-Kandari I, Al-Jadi M, Lefebvre C, Vigier L, Medeiros MD, Dashti HH, Knight R, Al-Qattan A, Chimmalgi VS, Datta K, Hafez KM, Turkey L, Bond DJ (2012). Results from a pilot water flood of the Magwa Marrat Reservoir and simulation study of a sector model contribute to understanding of injectivity and reservoir characterization. https://doi.org/10.2118/163360-ms

Allan J, Sun SQ (2003) Controls on recovery factor in fractured reservoirs: lessons learned from 100 fractured fields. In: SPE annual technical conference and exhibition, 5-8 October, Denver, Colorado

Alvarado V, Manrique E (2010) Field planning and development strategies. In: Enhanced oil recovery, Gulf Professional Publishing

Asadollahi M, Naevdal G (2009) Waterflooding optimization using gradient based. Methods. https://doi.org/10.2118/125331-ms

Brice BW, Renouf G (2008). Increasing oil recovery from heavy oil waterfloods. https://doi.org/10.2118/117327-ms

Brouwer DR, Jansen JD (2002). Dynamic optimization of water flooding with smart wells using optimal control theory. https://doi. org/10.2118/78278-ms

Craig F Jr, Geffen T, Morse R (1955) Oil Recovery performance of pattern gas or water-injection operations from model tests. Pet Trans 204:7-15

Dai Z, Viswanathan H, Middleton R, Pan F, Ampomah W, Yang C, Jia W, Xiao T, Lee SY, McPherson B, Balch R, Grigg R, White M (2016) $\mathrm{CO}_{2}$ accounting and risk analysis for $\mathrm{CO}_{2}$ sequestration at enhanced oil recovery sites. Environ Sci Technol 50:7546-7554. https://doi.org/10.1021/acs.est.6b01744

Dou L, Wang J, Wang R, Wei X, Shrivastava C (2018) Precambrian basement reservoirs: case study from the northern Bongor Basin, the Republic of Chad. AAPG Bull 102(9):1803-1824

Gharbi RB, Peters EJ, Garrouch AA (1997) Effect of heterogeneity on the performance of immiscible displacement with horizontal wells. J Pet Sci Eng 18:35-47. https://doi.org/10.1016/S0920 -4105(97)00016-8

Hadia N, Chaudhari L, Mitra SK, Vinjamur M, Singh R (2007) Experimental investigation of use of horizontal wells in waterflooding. J Pet Sci Eng 56:303-310

Ishak MA, Islam MA, Shalaby MR, Hasan N (2018) The application of seismic attributes and wheeler transformations for the geomorphological interpretation of stratigraphic surfaces: a case study of the f3 block, Dutch offshore sector, north sea. Geosciences (Switzerland) 8(3):79

Johns RT, Sah P, Solano R (2002) Effect of dispersion on local displacement efficiency for multicomponent enriched-gas floods above the minimum miscibility enrichment. SPE Reserv Eval Eng 5:4-10

Khan MY, Mandal A (2019) Vertical transmissibility assessment from pressure transient analysis with integration of core data and its impact on water and miscible water-alternative-gas injections. Arab J Geosci 12:261. https://doi.org/10.1007/s1251 7-019-4352-x

Klemm B, Picchioni F, Raffa P, van Mastrigt F (2018) Star-like branched polyacrylamides by RAFT polymerization, part II: performance evaluation in enhanced oil recovery (EOR). Ind Eng Chem Res 57:8835-8844. https://doi.org/10.1021/acs.iecr.7b033 68

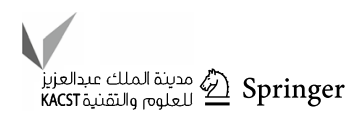


Kontorovich AE, Epov MI, Eder LV (2014) Long-term and mediumterm scenarios and factors in world energy perspectives for the 21st century. Russ Geol Geophys 55:534-543

Levitt D, Jouenne S, Bondino I, Santanach-Carreras E, Bourrel M (2013) Polymer flooding of heavy oil under adverse mobility conditions. In: SPE enhanced oil recovery conference, 2-4 July, Kuala Lumpur, Malaysia

Li G, Li XS, Li B, Wang Y (2014) Methane hydrate dissociation using inverted five-spot water flooding method in cubic hydrate simulator. Energy 64:298-306

Luo H, Delshad M, Pope GA, Mohanty KK (2017). Interactions between viscous fingering and channeling for unstable water/polymer floods in heavy oil reservoirs. https://doi.org/10.2118/18264 9-ms

Mohammadi H, Delshad M, Pope GA (2009) Mechanistic modeling of alkaline/surfactant/polymer floods. SPE Reserv Eval Eng 12:518527. https://doi.org/10.2118/110212-pa

Mohyaldin ME, Ismail MC, Hasan N (2019) A correlation to predict erosion due to sand entrainment in viscous oils flow through elbows. In: Lecture notes in mechanical engineering-advances in material sciences and engineering (SPRINGER/Scopus), pp 287-297

Morel DC, Vert M, Jouenne S, Gauchet R, Bouger Y (2012) First polymer injection in deep offshore field angola: recent advances in the Dalia/Camelia Field Case. Soc Pet Eng 1(2)

Ogbeiwi P, Aladeitan Y, Udebhulu D (2018) An approach to waterflood optimization: case study of the reservoir X. J Pet Explor Prod Technol 8:271-289. https://doi.org/10.1007/s13202-017-0368-5

Ogiriki SO, Agunloye MA, Abdulkashif AOG, Olafuyi O (2018) Exploitation of Bitumen from Nigerian Tar Sand using Hot-Water/ Steam Stimulation Process. Pet Coal 60(2)

Palsson B, Davies DR, Todd AC, Somerville JM (2003) The water injection process: a technical and economic integrated approach. Chem Eng Res Des 81(3):331-341

Qi D, Hesketh T (2005) An analysis of upscaling techniques for reservoir simulation. Pet Sci Technol 23:827-842. https://doi. org/10.1081/LFT-200033132

Rahman A, Happy FA, Ahmed S, Hossain ME (2017) Development of scaling criteria for enhanced oil recovery: a review. J Pet Sci Eng 158:66-79. https://doi.org/10.1016/j.petrol.2017.08.040

Saboorian-Jooybari H, Dejam M, Chen Z (2016) Heavy oil polymer flooding from laboratory core floods to pilot tests and field applications: half-century studies. J Pet Sci Eng 142:85-100. https:// doi.org/10.1016/j.petrol.2016.01.023

Saeid NH, Hasan N, Ali MHBHM (2018) Effect of the metallic foam heat sink shape on the mixed convection jet impingement cooling of a horizontal surface. J Porous Med 21:295-309

Sandrea I, Sandrea R (2007) Recovery factors leave vast target for EOR technologies. Oil Gas J 105:44-47

Saper MMM, Adam AAM, Bashar AAAS, Ali AAHAA (2018) A computer program for excess water production diagnosis case studyHeglig Oil Field-Sudan
Seright R (2010) Potential for polymer flooding reservoirs with viscous oils. SPE Reserv Eval Eng 13:730-740. https://doi. org/10.2118/129899-PA

Sern WK, Takriff MS, Kamarudin SK, Talib MZM, Hasan N (2012) Numerical simulation of fluid flow behaviour on scale up of oscillatory baffled column. J Eng Sci Technol 7:119-130

Sheng JJ, Leonhardt B, Azri N (2015) Status of polymer-flooding technology. J Can Pet Technol 54:116-126. https://doi. org/10.2118/174541-pa

Thomas CE, Mahoney CF, Winter GW (1987) Water-injection pressure maintenance and waterflood processes (ch 44). In: Bradley HB et al (eds) Petroleum engineering handbook. SPE, Richardson, p 44

Turta AT, Wassmuth F, Maini BB, Singhal AK (2000) Evaluation of IOR potential of petroleum reservoirs. In: and others (ed) Paper presented at the 16th world petroleum congress, Calgary, Canada, vol All Days

Weijermars R, van Harmelen A (2017) Advancement of sweep zones in waterflooding: conceptual insight based on flow visualizations of oil-withdrawal contours and waterflood time-of-flight contours using complex potentials. J Pet Explor Prod Technol 7:785-812. https://doi.org/10.1007/s13202-016-0294-y

Xin X, Yu G, Chen Z, Wu K, Dong X, Zhu Z (2018) Effect of polymer degradation on polymer flooding in heterogeneous reservoirs. Polymers 10(8):857

Yu W, Lashgari H, Sepehrnoori K (2014) Simulation study of $\mathrm{CO}_{2}$ Huff-n-Puff process in Bakken tight oil reservoirs. In: and others (ed) SPE Western North American and Rocky Mountain Joint Meeting, Denver, Colorado, SPE, vol SPE-169575-MS

Zene MTAM, Hasan N, Ruizhong J, Zhenliang G, Trang C (2019a) Volumetric estimation and OOIP calculation of the Ronier4 block of Ronier oilfield in the Bongor basin, Chad. Geomech Geophys Geo Energy Geo Resour 5(4):1-11

Zene MTAM, Hasan N, Ruizhong J, Zhenliang G, Trang C, Volume 9, Issue 4, pp 2461-2476, (2019b) Geological modeling and upscaling of the Ronier 4 block in Bongor basin. Chad. J Pet Explor Prod Technol 9(4):2461-2476

Zhalehrajabi E, Rahmanian N, Hasan N (2014) Effects of mesh grid and turbulence models on heat transfer coefficient in a convergentdivergent nozzle. Asia Pac J Chem Eng 9:265-271

Zhou C (2015) Variation laws of injection and production indexes of polymer flooding in primary and sub-layers in Daqing Oilfield. Fault Block Oil Gas Field 22(5):610-613

Publisher's Note Springer Nature remains neutral with regard to jurisdictional claims in published maps and institutional affiliations. 